\title{
Soil Conservation and Rural Institutions in Java
}

\section{Ken Pickering}

Indonesia's soil erosion, which endangers the livelihoods of some two-thirds of present and future generations of the world's fifth largest population, is one of today's most serious ecological problems. Growing government concern over the last decade and more led in 1976 to the launching of a huge reforestation programme, with fund allocations in the last three years of Rupiahs 76 billion (equivalent to some $\$ 184$ million before the Novem ber 1978 devaluation). While this programme has some substantial physical achievement to its credit, especially on the State owned forest lands, its implementation has shed new light on the character of the problem itself. Without minimising the importance of continuing scientific research, it seems that the more intractable difficulties of containing soil erosion lie less in the areas of technology and economics than in their social and political dimensions. The problem is seen now as essentially one of management, and because time is limited the success or failure of future soil conservation programmes may well depend on the speed with which institutions can be effectively modernised and public service management decentralised. This article attempts to analyse the main issues in the problem but must begin with the caution that such a complex tople cannot be described in a short article without some selectivity and risk of over-simplification. A second preliminary note is that the focus is entirely on the inner islands of Indonesia where population pressures are greatest and terrain most mountainous and where, in consequence, problems of soil erosion are substantially different from those of the outer islands. The concern therefore is with Java, Madura and Bali, though for convenience these are collectively referred to as Java.

Briefly stated, the ecological problem in these islands arises from, population growth this century which has increasingly forced rural cultivators from the valleys into dry-land (tegalan) farming and brought about the deforestation of once thickly wooded hills and mountain slopes. The scale on which this is now taking place is such that over much of Java watershed erosion reaches $3.5 \mathrm{~cm}$ a year and millions of tons of soil are washed into the sea annually. Thus soil fertility is reduced; hydrological balances are disturbed; wells dry up or have diminished discharges; less water is available for irrigating the plains and lower slopes; and there is a steady increase in both the frequency and size of floods and in the silting up of rivers, irrigation canals and reservoirs. In extreme instances the upper slopes are so denuded of soil they have been abandoned for cultivation. The great majority of Java's slopes, however, has not yet reached the point of no return and there is still time for a wide-scale soil conservation programme to be effective.

In very broad terms remedial measures fall into two categories: soil mechanics and afforestation. Soil can be conserved for food crops and surface run-offs reduced to five per cent or less depending on the quality and permeability of the soil - by 'bench' terracing with appropriate waterways to channel the water along the back of the terrace and, usually necessary in Java, by constructing 'gulley-plugs' to control the downward flow of run-off water to its eventual discharge. Secondly, afforestation can be an excellent means of reducing erosion and controlling flooding. Given appropriate choice of trees and good management of forests, erosion is checked by soil litter; run-off is small because of the higher permeability of forests soils; and nutrients are better preserved since they are stored in the vegetation within the existing organic system. Common to all forms of vegetation for erosion control is the need to provide cover for the soil. On exposed lands Hudson's work in East Africa has shown the importance in the tropics of 'rain-drop splash' - the first stage in the water erosion process which leads to the successive stages of 'run-off', 'gulley', and 'steam-bank' erosion (Hudson, 1971, 4776). In one experiment, he showed how, by using a fine wire gauze, rate of soil loss could be reduced from a ten year average of 126.6 tons per hectare to 0.9 tons $\mathrm{p}$.ha, and in subsequent experiments, how similar effects can be achieved with close planted food crops such as maize. On forest lands, as an 1974 FAO report on Central Java states, "in forests with bare soils erosion is still considerable. In establishing forests, especially on abandoned sites without vegetation, it is essential to give as much attention to establishing a good soil cover as to establishing the trees". (UNDP/FAO, 1976). 
From the 1960s onwards these considerations led to changes in Indonesian forest policy, especially in the government-owned lands run by the State Forest Corporation, Perhum Perhutani. Traditional forest usage had been threefold: watershed protection through permanent tree cover; industrial forest maintained to produce raw materials; and forests for other purposes such as wildlife preservation and recreation. These policies were modified in the more populous areas to include forms of forest management which offered more employment and opportunities for agrisilviculture. Interplanting of food crops wth young trees in the first two years of plantation was introduced and spread to some 10,000 hectares by 1978 . Under these schemes farmers are assisted with both crops, though after two years food crops are banned and the forest reverts to Perhum Perhutani. On private lands the Forest Department launched new schemes during the First Plan period designed to encourage farmers to plant trees among their food crops.

When in 1975 large sums of money were made available a modification of these ideas was used as a basis for launching the new programme. Roughly half the funds went to Perhum Perhutani and half to programmes on private land. But it was recognised that in degree of control and regulation of farmers activities there was a great difference between public and private land programmes, and that the latter called for a much greater emphasis on persuasion than was needed for the relatively small populations of forest dwellers in government owned forests.

It was also recognised that the problem of erosion on private lands was too widespread and too advanced to be dealt with from the resources of any one central Department or Ministry. For these reasons the 'Inpres' form of programme (deriving from the words "Instruction of the President") was adopted, under which overall responsibility in the field was assigned to the Bupati (District Head) under the Provincial Governors. The Bupatis would exercise local control of programmes through the Camats (heads of sub-districts), and the Lurahs (village heads). Bappenas (the Planning Commission). the Forest Department and the Ministry of Agriculture would supply assistance with planning, co-ordination, and evaluation, and technical guidance for activities in the field. Administrative instructions to Regional Governments would be issued by the Ministry of Home Affairs.
In the event the date of the decision to launch the programme left only some four months of preparation before the beginning of the financial year, which led to heavy dependence upon the central planners in Bappenas and the Ministries of Agriculture and Home Affairs. It also emphasised, in selecting strategies, the attractions of concentrating investment upon a known and relatively manageable technology with a tried budgeting system which could be used in all regions. In retrospect later programme evaluators were to ascribe three consequences to the early centralisation of decision-making for the programme. First, the determination of the extent and location of soil erosion in each Kabupaten, and hence the amount of allocations for the programme, depended on centrally collated statistics which, programme experience was to show, had not kept up with the rapidly changing land-use patterns of recent years. Secondly, though not exclusively as will be seen, it contributed to an unduly large investment in the private land programme in one technology that of tree planting on the lower slopes. Thirdly, the reliance upon targets imposed from above and controls exercised through the Bupati-CamatLurah network precluded any potential contribution to planning and management by the people themselves. By 1977 there was a growing recognition in the Bappenas and the Ministries of the Interior and Agriculture that an effective programme to contain soil erosion called for a different approach to management. The evaluation reports of the Forest Department and the findings of its conferences consistently referred to the need to transfer from what is called a 'top-down' to a 'bottom-up' approach. The FAO-assisted project in central Java in the Upper Solo river basin, which between 1973 and 1976 shed much valuable light on soil conservation, recommended in its final report that the programme should be launched only in those villages which requested it. The Ministry for Supervision of Development and the Environment established in 1978 now stresses the essential dependence in watershed management on community understanding and direct involvement of the cultivator himself.

These changes in attitude reflect the growing recognition, strengthened by programme experience since 1976, that as it is the farmers themselves who are responsible for the serious extent of soil erosion in Java, it is only through their understanding, initiatives, and organisation that the process can be arrested. In examining this further, it is helpful in the light of current 
experience, to consider both what is known and what it is now reasonable to expect, of farmers' responses to the three most important technologies for conserving soils on Java.

\section{Ridge and tree planting}

Ridge and tree-planting technology on private lands has been the central technology to date. Unlike 'bench' terracing this does not involve cutting into the slopes of hills to produce tillage areas; rather, as its name implies, it means building small parallel ridges along the contours in which fuel wood coppice trees such as Calliandra can be closely planted. When trees can be regularly cut back and regrown from coppice shoots an effective barrier against erosion can be established. Moreover, in time rain brings some natural levelling of the tillage area between the ridges which can then be cultivated with reduced soil loss. For the system to be effective, however, it is imperative that the farmers, especially in the long rainy season, constantly inspect and maintain the ridges. Since stored water concentrates at the weakest point a break in the ridge can lead to gully erosion more serious in its effects than the sheet erosion which would occur if there were no ridges. This means that badly constructed or poorly maintained ridges can actually increase soil erosion.

Though evaluation is not yet complete, experience in Java suggests that while farmers can be induced to construct ridges and plant the tree seedlings supplied they are often less less willing to maintain them. In extreme instances seedlings have been pulled up soon after planting so that the favourable soil of the ridges can be planted with cassava which, as a root crop, on harvesting tends to increase the soil's detachability under raindrop impact and hence its erodibility.

Commonly also, farmers will maintain fuel wood trees for a year and a half or more but pull them up when spreading branches begin to prevent the sun's rays from reaching their foodcrops. A Forest Department Conference of early 1978 studied slides of one project where farmers, to comply with a locally imposed regulation that trees must be preserved yet still protect their foodcrops, had clipped the branches of trees into a narrow rectangle which not only threatened tree survival but remowed the protection of the tree canopy against raindrop splash. Though an isolated instance, this provided a spectacular example of the dangers of overcentralised planning for such a programme. Overall, available evidence suggested the technology was working best in the areas with poorer soils where foodcrops are less productive and where in consequence income from fuel wood was more attractive to the farmer.

Thus, by the third year of the programme the extent to which the ridge tree-planting technology, however appropriate for state forests, should be applied to private land was being seriously questioned. Two lessons emerged. First, the essential condition of success in the ridge tree-planting programme was that farmers should understand and welcome its long-term benefits and have a financial interest in carrying out the required maintenance. Second, the technology had social validity only in a much smaller area than it was technologically sound; in many areas it would have to give way to other technologies if, even though less manageable and more costly from the departmental standpoint, they were more acceptable to the farmers themselves.

Both cases called for direct popular involvement in planning and indicated the need for some form of farmers' organisation to pull things together at village level. Meanwhile a problem of physical resources for the programme, a direct result of experience, led in 1978 to the introduction of one important measure toward local control. So large a tree-planting programme quickly gave rise to the problems of producing tree seedlings in the numbers required. The smaller needs of earlier programmes had been met by nurseries maintained by the Ministries of Agriculture and the Forestry Research Institutions. These proved inadequate for the needs of the expanding programme and also created a problem of quality in that many kinds of tree-seedlings do not easily survive long journeys by truck. Yet theoretically there was no good reason to prevent individual villages with some technical support from establishing and managing their own forest nurseries. In 1978 the Forest Department began to put this idea into practice and launched training courses in nursery management for locally selected staff drawn from rural areas.

\section{Bench terracing}

The second technology is that of bench-terracing where the requirements from the farmer are of a different order. Bench terracing with waterways drop-channels and gulley plugs has been developed on tegalan slopes with substantial success in Java, most notably and extensively in the Upper Solo valley by the FAO assisted project under the Forest Department. Well-constructed 
and well-maintained terraces have been shown to reduce soil loss to five per cent or less. Moreover, on the more fertile and porous soils recent studies at Penewangan in West Java show that indigenous systems of level terracing, even without the costly provision of drop-channels, can provide adequate protection against soil erosion. In the more populous areas therefore, where land hunger is most acute, bench terracing can be both a more effective and a more economically attractive technology than agrisilviculture.

Planners in 1976, however, were prevented by three main difficulties from investing in bench terracing at the outset of the programme. First, especially where drop channels and gulley plugs are needed, traditional farming skills, at least in the early stages, have to be supplemented by para-technical staff departmentally trained in soil conservation skills and the use of levelling instruments. This called for new and intensive training for field staff for which time and preparation was needed: in the event a beginning was made in the second year.

Secondly, bench terracing is highly labour intensive, requiring 1,000 to 1,500 man-days of labour per hectare (depending on the angle of slope), compared with 40 man-days per hectare required for the ridges in the tree planting programme. The problem is compounded by climate, since terracing is easier done at the end of the dry season and the beginning of the rains when labour is in demand for other farming activities. The Solo project had relied heavily on labour attracted from neighbouring districts by food 'packages' under the World Food Programme. Shortage of labour on the middle slopes was believed to be a major factor, along with some lack of belief in their usefulness, in holding back farmers on the tegalans from constructing bench terraces of their own. Not surprisingly therefore some planners saw the labour question as a major problem, the more so because they doubted the feasibility of mobilising surplus labour from outside the tegalans and bringing it to scattered project sites. Thirdly, it was then though, to plan bench terracing projects called for detailed land-use maps and sophisticated contour surveys based on aerial photography which would not be available for some years.'

However, largely as a consequence of the programme and the closer communication between farmers and field staff it has brought about, some of these earlier assumptions have now been reviewed. First, there is now evidence to believe that the reason so little bench terracing on Java's tegalans is undertaken is less a consequence of lack of understanding by farmers about the dangers of erosion and the advantages of good terraces in controlling it than a consequence of poverty.

The marginal or near marginal farmer cannot afford to pay the labour needed nor is he able to sustain the temporary loss of food crops which terracing entails. Such bench terracing on the tegalans as is to be found is carried out by wealthier farmers who are not dependent upon only one source of land income. ${ }^{1}$ Secondly, labour availability is now regarded as less of a constraint. Studies in West and Central Java have shown that landless labourers will travel substantial distances if wages are adequate and punctual, and many instances have come to light of village capacity to share labour on a cooperative basis. Thirdly, on land-use and land ownership villàge records are certainly the most accurate available; they form the basis in fact of IPEDA, Indonesia's land tax. In many Kelurahans it is possible to discover who owns how much land, how holdings are fragmented, and the uses to which land is put.

\section{Silvipasture}

The last of the three technologies, silvipasture, produces by far the most complex problems both of social engineering and scientific research. The Forest Department and FAO in Java make a general distinction between slopes of varying steepness. On slopes of less than 50 per cent treatment consists of fuelwood tree planting and bench terracing for food crops. On slopes above 50 per cent, where erosion is usually too far advanced to make terracing for agriculture profitable, the policy is to plant trees for fuelwood and to interplant them with grasses for stall feeding and fattening animals for the market. In this way a farmer receives income to replace the loss of his cassava both from fuelwood and animals. Space constraints preclude all but a brief summary of the important trees/ fodder/livestock (TFL) technology on which experience to date - almost all of it in the Upper Solo river basin - has posed many new problems

\footnotetext{
1 Farmers in Java are normally in one of four categories. In the River Solo valley the local terms to describe them are 'kuli kenceng' or 'full' farmer: a farmer with access to wet rice fields. dry fields, and 'home garden' (pekarangan). 'Setengah Kenceng' or "half-full' farmer: a farmer who has only tegalan and pekarangan. 'Magersari': a farmer who lives on a plot of someone else's land in exchange for cultivating that plot. "Mondoimpot'. a farmer who have have a home garden plot but derives his income mainly
} 
while resolving others. Scientific research is still very necessary to develop work already done on questions such as the adaptability of various tree species to different soils, individually or in combination with others, the testing of grasses and legumes, and the best methods of using fertilisers. On management issues observation of experience to-date appears to support three broad conclusions.

First, under present arrangements for the programme, there is an important connection between success or failure and the size of landholdings. In one very effective project where farmers use mainly Albizzia Falcataria and Pinus Merkusii in combination with elephant grass, village records showed that all the farmers concerned owned additional land outside the project area and 75 per cent were Kuli-Kenceng. By contrast, in a topographically comparable neighbouring project using the same trees and grasses, but where investigation showed over 50 per cent of the trees to have been destroyed, the records showed all the land to be rented.

Secondly, there was evidence that traditional departmental organisation with the locus of control far from the remote TFL project areas produced extreme problems of logistics and synchronised timing of inputs. Marginal farmers faced with delays in receiving fertiliser or animals might have little option but to resort to cassava.

Thirdly, for the marginal farmer at least, the silvipasture technology produces a temptation he may find hard to resist in that he is required to observe a regimen over a span of years for felling his trees. If, for example, eucalyptus alba is used he may cut one third of his trees in the third year, a second third in the sixth, and half the remaining stand in the tenth. Illness, debt and insecurity of tenure are only some of the factors which may lead him to clearfell his whole stand when it is big enough to be marketable and thus defeat the purpose of the scheme.

Overall, Indonesian planners are agreed that despite the need for more scientific research the silvipasture technoløgy makes economic sense, but if it is also to make sociological sense for marginal farmers management systems must achieve a new degree of intimacy with local projects.

In all three technologies, therefore, experience from the current programme supports the belief of the Forest Department and the Ministry of the Environment that a novel measure of decentralisation and rural institution-building is essential to successful soil conservation.

There is clearly a vast difference between rural development disciplines in the amount of decentralisation which is either practicable or desirable. For example the Inpres Kabupaten programme provides bridges, roads, culverts, small irrigation facilities, bus shelters and other minor public works by using construction skills which already exist in the Kabupatens. It therefore made sense for the Kabupatens to be given the tasks of deciding where such facilities are most needed and the priority to be given to competing demands and of advertising for tenders, and appointing and supervising contractors. It would not have made sense however, at least in its initial stages, for the Family Planning programme to have been similarly decentralised since it was a new programme involving hitherto unknown skills which had to be centrally developed before they could be diffused through the provinces.

The uniqueness of the soil conservation programme in this context lies perhaps in three factors. The first is in the character and range of the essential local decisions to be made in projects. Questions such as land-ownership or land-use entitlement, use of irrigation water, and delineation of boundaries between holdings can be resolved only at village level. Secondly, the problems of input management and inter-agency co-ordination are unprecedented in scale or complexity in other rural programmes; a dozen departments can be directly involved with inputs to many thousands of projects scattered all over Java. Farmers unions or Village Erosion Committees established to complement or supplement the village government of the overburdened Lurah and organised to handle payments for labour, to manage forest nurseries and to distribute fertiliser, animals and other inputs would relieve many of the severe logistic and personnel problems for central departments in the field. The third and critical factor is the problem of ensuring responsible management of inputs by farmers themselves. No system, however perfect, can prevent all abuses: the best that can be hoped for is that the level of abuse is kept to acceptable proportions. There are farmers who sell animals or fertiliser as soon as they receive them, others who exaggerate the mortality rate of their tree seedlings as excuse to replace them with cassava. There are lazy 
farmers who fail to maintain terraces and thereby increase the potential for erosion on the land of their neighbours further down the slope. In a very small-scale programme it may be possible to ensure compliance with accepted obligations through intensive supervision, but this cannot be a realistic policy for so large and diffuse a programme as is necessary - and the the steeper slope farmers in particular are the most physically remote of the village community. The arguments which are now leading some programme officers and researchers to believe that the problem can best be handled by appropriate village institutions seem to be based on three ideas. First, the more detailed planning at village level they would make possible and the use of local knowledge, not only of physical conditions but of individual farmers in the community would reduce many of the present unavoidable anomalies in planning which contribute to untoward practices. Secondly, more local control over the activities of govern- ment departments in the field can be expected to increase public confidence in the programme. Thirdly, the exercise of responsibility for the programme may be the best way of bringing home to the local community the essential characteristic in soil erosion of mutual dependence and the vulnerability of some farmers to the activities of others, and lead to their imposing their own sanctions where required upon its members. Given the circumstances of the programme these may be the only sanctions which can be effective.

\section{References}

Hudson, Norman, 1971, Soil Conservation, Batsford, London

UNDP/FAO, 1976, General Management and Development Plan for the Samin Watershed, Working Paper no. 31, Solo, Indonesia 